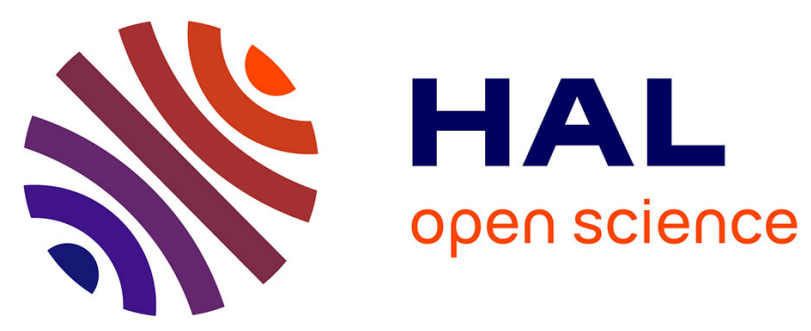

\title{
Vascular Nd:YAG laser: a therapeutic alternative for large venous lakes of the oral mucosa
}

L. Costa Mendes, S. Laurencin-dalicieux, C. Paul, C. Bulai Livideanu, S. Cousty

\section{> To cite this version:}

L. Costa Mendes, S. Laurencin-dalicieux, C. Paul, C. Bulai Livideanu, S. Cousty. Vascular Nd:YAG laser: a therapeutic alternative for large venous lakes of the oral mucosa. Journal of the European Academy of Dermatology and Venereology, 2020, 34 (4), 10.1111/jdv.16110 . hal-02967861

\section{HAL Id: hal-02967861 \\ https://hal.science/hal-02967861}

Submitted on 15 Oct 2020

HAL is a multi-disciplinary open access archive for the deposit and dissemination of scientific research documents, whether they are published or not. The documents may come from teaching and research institutions in France or abroad, or from public or private research centers.
L'archive ouverte pluridisciplinaire HAL, est destinée au dépôt et à la diffusion de documents scientifiques de niveau recherche, publiés ou non, émanant des établissements d'enseignement et de recherche français ou étrangers, des laboratoires publics ou privés. 
archives-ouvertes

\section{Vascular Nd:YAG laser: a therapeutic alternative for large venous lakes of the oral mucosa}

L. Costa Mendes, S. Laurencin-dalicieux, C. Paul, C. Bulai Livideanu, S. Cousty

\section{- To cite this version:}

L. Costa Mendes, S. Laurencin-dalicieux, C. Paul, C. Bulai Livideanu, S. Cousty. Vascular Nd:YAG laser: a therapeutic alternative for large venous lakes of the oral mucosa. Journal of the European Academy of Dermatology and Venereology, Wiley, 2020, 34 (4), 10.1111/jdv.16110 . hal-02967861

\section{HAL Id: hal-02967861 \\ https://hal.archives-ouvertes.fr/hal-02967861}

Submitted on 15 Oct 2020

HAL is a multi-disciplinary open access archive for the deposit and dissemination of scientific research documents, whether they are published or not. The documents may come from teaching and research institutions in France or abroad, or from public or private research centers.
L'archive ouverte pluridisciplinaire HAL, est destinée au dépôt et à la diffusion de documents scientifiques de niveau recherche, publiés ou non, émanant des établissements d'enseignement et de recherche français ou étrangers, des laboratoires publics ou privés. 


\begin{tabular}{|c|c|c|c|l|l|}
\hline \multirow{2}{*}{$\mathcal{2}$} & J D V & \multicolumn{1}{|c|}{$\mathbf{1 6 1 1 0}$} & \multirow{2}{*}{ WILEY } & Dispatch: 6.12.19 & CE: Menaka S \\
\cline { 2 - 3 } \cline { 5 - 6 } & Journal Code & Manuscript No. & & No. of pages: 2 & PE: Sudhakar Seenivasan \\
\hline
\end{tabular}

\section{Vascular Nd-YAG laser: a therapeutic alternative for large venous lakes of the oral mucosa}

Editor

4 Venous lakes are benign vascular anomalies often present on the

5 lips and oral mucosa. ${ }^{1}$ Although different treatment modalities have been described, no standardized treatment is yet established, especially in the case of large venous lakes of the oral mucosa $(\geq 10 \mathrm{~mm})$. We report, here, two cases of patients successfully treated for intra-oral large venous lakes with a single 6 session of long-pulsed Nd-YAG laser.

The first patient, a 67 -year-old female, presented a $20 \mathrm{~mm}$ venous lake on the buccal mucosa and an $18 \mathrm{~mm}$ lesion on the dorsal surface of the tongue (Fig. 1). The second patient was a 68 -year-old female with a $15 \mathrm{~mm}$ venous lake on the inner side of the upper lip. She had a history of major ballistic trauma with peri-oral scarring (Fig. 2). Treatment of these venous lakes was indicated because the patients experienced chronic biting and bleeding.

For both patients, we used a vascular long-pulsed Nd-YAG laser with the following parameters: $1064 \mathrm{~nm}$ wavelength, $7 \mathrm{~mm}$ spot size, $100 \mathrm{~J} / \mathrm{cm}^{2}$ energy and a pulse width of $20 \mathrm{~ms}$. The laser beam was swept over the venous lakes for a few seconds, without overlapping. The end point was characterized by the hardening of the lesion, the whitening of its centre and an audible snap. No alteration of the mucosal surface was noted in the immediate postoperative period but diascopy showed a non-blanchable lesion. Local anaesthesia was not necessary, and the use of the laser's dynamic cooling device was sufficient to ensure the patients' comfort. The postoperative outcome was uneventful, and none of the patients experienced pain or bleeding. The first reassessment at 1 week showed a complete disappearance of the lesions for both patients. At 5 months and 1-year follow-ups, the results were stable: no relapse or scarring was noted.

The effectiveness of long-pulsed Nd-YAG laser in the treatment of venous lakes lies in the fact that its $1064 \mathrm{~nm}$ wavelength is preferentially absorbed by methemoglobin and has deep surface penetration of $4-7 \mathrm{~mm}^{2-5}$ Its photocoagulating effect allows therefore the specific targeting of the venous tissue, decreasing the possibility of relapse, and presents sufficient penetration for the treatment of deep-seated lesions. Several types of lasers have been used for the treatment of venous lakes of the lips and vascular malformations of the oral mucosa, including diode laser, ${ }^{6}$ pulse-dye laser ${ }^{7}$ and argon laser. ${ }^{8}$ Although these seem effective for superficial and small lesions, the longer wavelength of the Nd-YAG laser allows better and quicker results in the treatment of deeper and thicker lesions ${ }^{1}$ : a single session is often sufficient for the treatment of venous lakes of the lips and oral mucosa and provides stable results over time. ${ }^{4,5,9,10}$ Nd-YAG seems also to be better tolerated than argon and diode lasers
Figure 1 (a): $20 \mathrm{~mm}$ venous lake of the right buccal mucosa. The patient experienced recurrent biting and bleeding. (b): $18 \mathrm{~mm}$ venous lake on the dorsal surface of the tongue. (c): Outcome at 1year follow-up: complete disappearance of the buccal venous lake and stability of the results. (d): Outcome at 1-year follow-up: complete disappearance of the lingual venous lake, no relapse is noted.

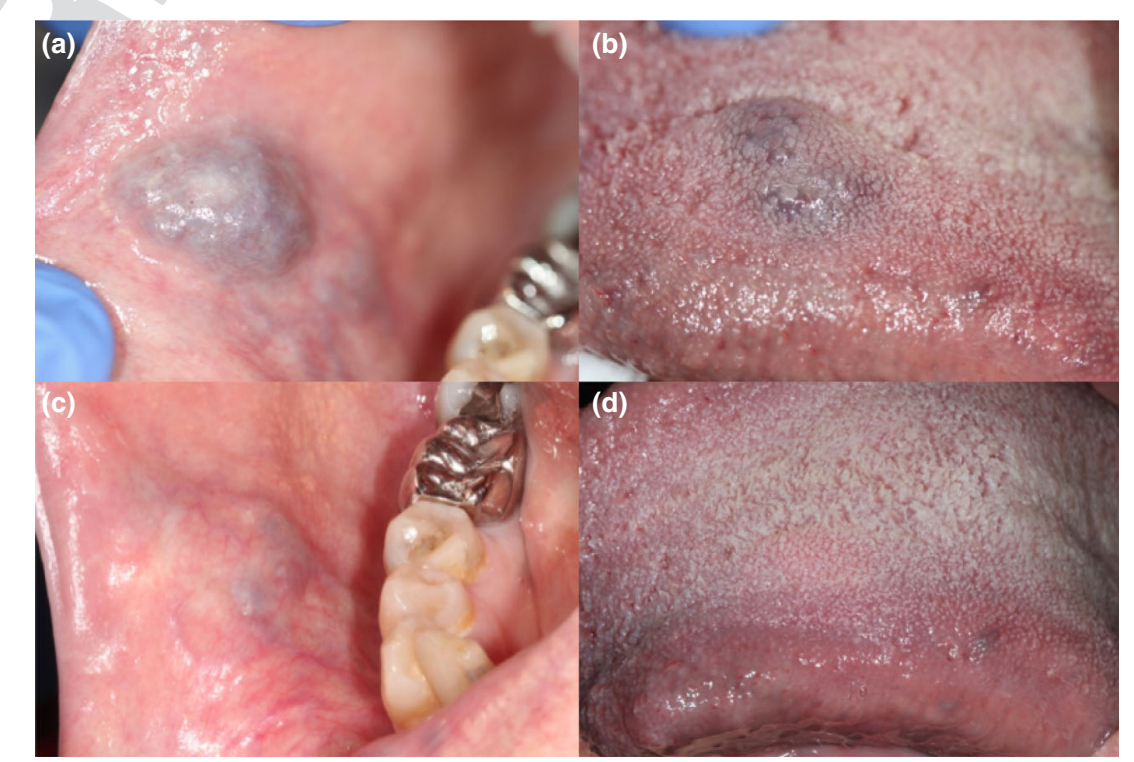



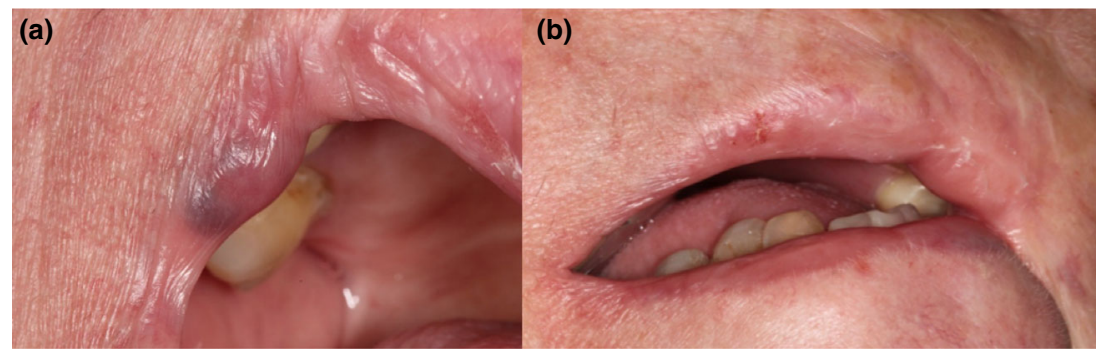

Figure 2 (a): $15 \mathrm{~mm}$ venous lake on the inner side of the right upper lip. The patient complained of chronic biting and bleeding. (b): Result at 1-year postoperatively. No scarring is noted on the treated site.

since these do not dissipate heat as well as the Nd-YAG laser, increasing the likelihood of tissue damage following treatment. ${ }^{1}$ Finally, the procedure generates minimal discomfort peri- and postoperatively. Although several authors reported the use of topical or local anaesthetics, we found it was not necessary if a cooling device is used. Surgery or sclerotherapy is most commonly described for large venous lakes of the lips. However, these techniques are more invasive than laser treatment and can often leave residual scarring, which can be problematic in multioperated patients or patients presenting several vascular lesions, such as our second patient.

Long-pulsed Nd-YAG laser is therefore a simple, non-invasive and effective technique for the treatment of venous lakes of the oral mucosa that can be proposed at the first consultation.

\section{Costa Mendes, ${ }^{1}$ (ID S. Laurencin-Dalicieux, ${ }^{1}$ C. Paul, ${ }^{2}$} C. Bulai Livideanu, ${ }^{2, *}$ (iD) S. Cousty ${ }^{1}$

${ }^{1}$ Oral Mucosal Pathology Consultation, Department of Dental Medicine, Toulouse University Hospital, Paul Sabatier University, Toulouse, France, ${ }^{2}$ Department of Dermatology, Toulouse University Hospital, Paul Sabatier University, Toulouse, France ${ }^{\star}$ Correspondence: C. Bulai Livideanu. E-mail: livideanu.c@ chu-toulouse.fr

\section{References}

1 Mlacker S, Shah VV, Aldahan AS, McNamara CA, Kamath P, Nouri K. Laser and light-based treatments of venous lakes: A literature review. Lasers Med Sci 2016; 31: 1511-1519.
2 Asai T, Suzuki H, Takeuchi J, Komori T. Effectiveness of photocoagulation using an Nd:YAG laser for the treatment of vascular malformations in the oral region. Photomed Laser Surg 2014; 32: 75-80.

3 Crockett DJ, Meier JD, Wilson KF, Grimmer JF. Treatment of oral cavity venous malformations with the Nd:YAG laser using the underwater technique. Otolaryngol Head Neck Surg 2013; 149: 954-956.

4 Eivazi B, Wiegand S, Teymoortash A, Neff A, Werner JA. Laser treatment of mucosal venous malformations of the upper aerodigestive tract in 50 patients. Lasers Med Sci 2010; 25: 571-576.

5 Medeiros R, Silva IH, Carvalho AT, Leão JC, Gueiros LA. Nd:yAG laser photocoagulation of benign oral vascular lesions: a case series. Lasers Med Sci 2015; 30: 2215-2220.

6 Bacci C, Sacchetto L, Zanette G, Sivolella S. Diode laser to treat small oral vascular malformations: a prospective case series study. Lasers Surg Med 2018; 50: 111-116.

7 Cheung ST, Lanigan SW. Evaluation of the treatment of venous lakes with the 595-nm pulsed-dye laser: a case series. Clin Exp Dermatol 2007; 32: $148-150$.

8 Neumann RA, Knobler RM. Venous lakes (Bean-Walsh) of the lipstreatment experience with the argon laser and 18 months follow-up. Clin Exp Dermatol 1990; 15: 115-118.

9 Yang HY, Zheng LW, Yang HJ, Luo J, Li SC, Zwahlen RA. Long-pulsed $\mathrm{Nd}$ :YAG laser treatment in vascular lesions of the oral cavity. J Craniofac Surg 2009; 20: 1214-1217.

10 John HE, Phen HS, Mahaffey PJ. Treatment of venous lesions of the lips and perioral area with a long-pulsed Nd:YAG laser. Br J Oral Maxillofac Surg 2016; 54: 376-378.

DOI: $10.1111 / j d v .16110$ 